\title{
Magnetic Resonance Imaging of Sacroiliitis in Patients with Spondyloarthritis: Correlation with Anatomy and Histology
}

\section{Magnetresonanztomografie der Sakroiliitis bei Patienten mit Spondyloarthritis: Korrelation mit Anatomie und Histologie}

Authors

Affiliations

\author{
K.-G. A. Hermann ${ }^{1}$, M. Bollow ${ }^{2}$
}

Department of Radiology, Charité Medical School, Campus Mitte, Berlin

Department of Diagnostic and Interventional Radiology and Nuclear Medicine, Augusta Hospital, Bochum
Key words

skeletal-axial

- MR imaging

- inflammation

arthritides

\section{Zusammenfassung}

$\nabla$

Die Magnetresonanztomografie (MRT) der Sakroiliakalgelenke hat sich als probates Mittel zur Frühdiagnostik der Sakroiliitis bei inkonklusivem Röntgenbild etabliert. Ein positiver MRT-Befund hat dabei eine ähnlich hohe Bedeutung wie der Nachweis von HLA-B27. Der Nachweis der Sakroiliitis in der Bildgebung ist einer der Schlüsselbefunde in der Klassifikation der axialen Spondyloarthritis ensprechend der Kriterien der Assessments in Ankylosing Spondylitis (ASAS) Gruppe. Frühe Zeichen der Sakroiliitis sind die Enthesitis des artikulären Faserknorpels, Kapsulitiden und Osteitiden. In späteren Stadien kommen strukturelle (chronische) Veränderungen hinzu, dazu gehören Fettdepositionen, Erosionen, subchondrale Sklerosierungen und transartikulären Knochenbrücken bis hin zur Ankylose. Diese MRT-Befunde werden histologischen Darstellungen von Gelenkbiopsaten gegenüber gestellt. Bei

received 5.1.2013 accepted 19.7.2013

Bibliography

Dol http://dx.doi.org/

10.1055/s-0033-1350411

Published online: 2.9.2013

Fortschr Röntgenstr 2014; 186 : 230-237 @ Georg Thieme

Verlag KG Stuttgart · New York . ISSN 1438-9029

\section{Correspondence}

PD Dr. Kay-Geert A. Hermann Institut für Radiologie, Charité Universitätsmedizin Berlin,

Campus Mitte

Charitéplatz 1

10117 Berlin

Germany

Tel.: ++ 49/30/450527082

Fax: $++49 / 30 / 450527905$

kghermann@gmail.com aktiver Sakroiliitis dominiert histologisch ein proliferatives, pannusartiges Bindegewebe, welches Knorpel und Knochen destruiert. Dieses besteht neben Fibroblasten und Fibrozyten aus T-Zellen und Makrophagen. Später dominieren von neu gebildetem Knochen umgebene Knorpelinseln sowie Reste zellulärer Infiltrate. Kenntnisse der Morphologie der Sakroiliakalgelenke und der pathologischen Mikro- und Makroanatomie der Sakroiliitis sind hilfreich für das Verständnis der magnetresonanztomografischen Befunde.

\section{Sacroiliitis and Spondyloarthritis}

Sacroiliitis is an important clinical and diagnostic feature of ankylosing spondylitis (AS) [1] and

\section{Abstract \\ $\nabla$}

Magnetic resonance imaging (MRI) of the sacroiliac joints (SIJs) has become established as a valuable modality for the early diagnosis of sacroiliitis in patients with inconclusive radiographic findings. Positive MRI findings have the same significance as a positive test for HLA-B27. Sacroiliitis is one of the key features of axial spondyloarthritis (SpA) in the classification proposed by the Assessments in Ankylosing Spondylitis (ASAS) group. Early signs of sacroiliitis include enthesitis of articular fibrocartilage, capsulitis, and osteitis. In more advanced disease, structural (chronic) lesions will be visible, including periarticular fatty deposition, erosions, subchondral sclerosis, and transarticular bone buds and bridges. In this article we describe magnetic resonance (MR) findings and provide histologic biopsy specimens of the respective disease stages. The predominant histologic feature of early and active sacroiliitis is the destruction of cartilage and bone by proliferations consisting of fibroblasts and fibrocytes, Tcells, and macrophages. Advanced sacroiliitis is characterized by new bone formation with enclosed cartilaginous islands and residual cellular infiltrations, which may ultimately lead to complete ankylosis. Knowledge of the morphologic appearance of the sacroiliac joints and their abnormal microscopic and gross anatomy is helpful in correctly interpreting MR findings.

Citation Format:

- Hermann KGA, Bollow M. Magnetic Resonance Imaging of Sacroiliitis in Patients with Spondyloarthritis: Correlation with Anatomy and Histology. Fortschr Röntgenstr 2014; 186: 230-237

other forms of spondyloarthritis (SpA) [2]. While sacroiliitis can be diagnosed by conventional radiography in established disease, a more sensitive diagnostic tool such as magnetic resonance 

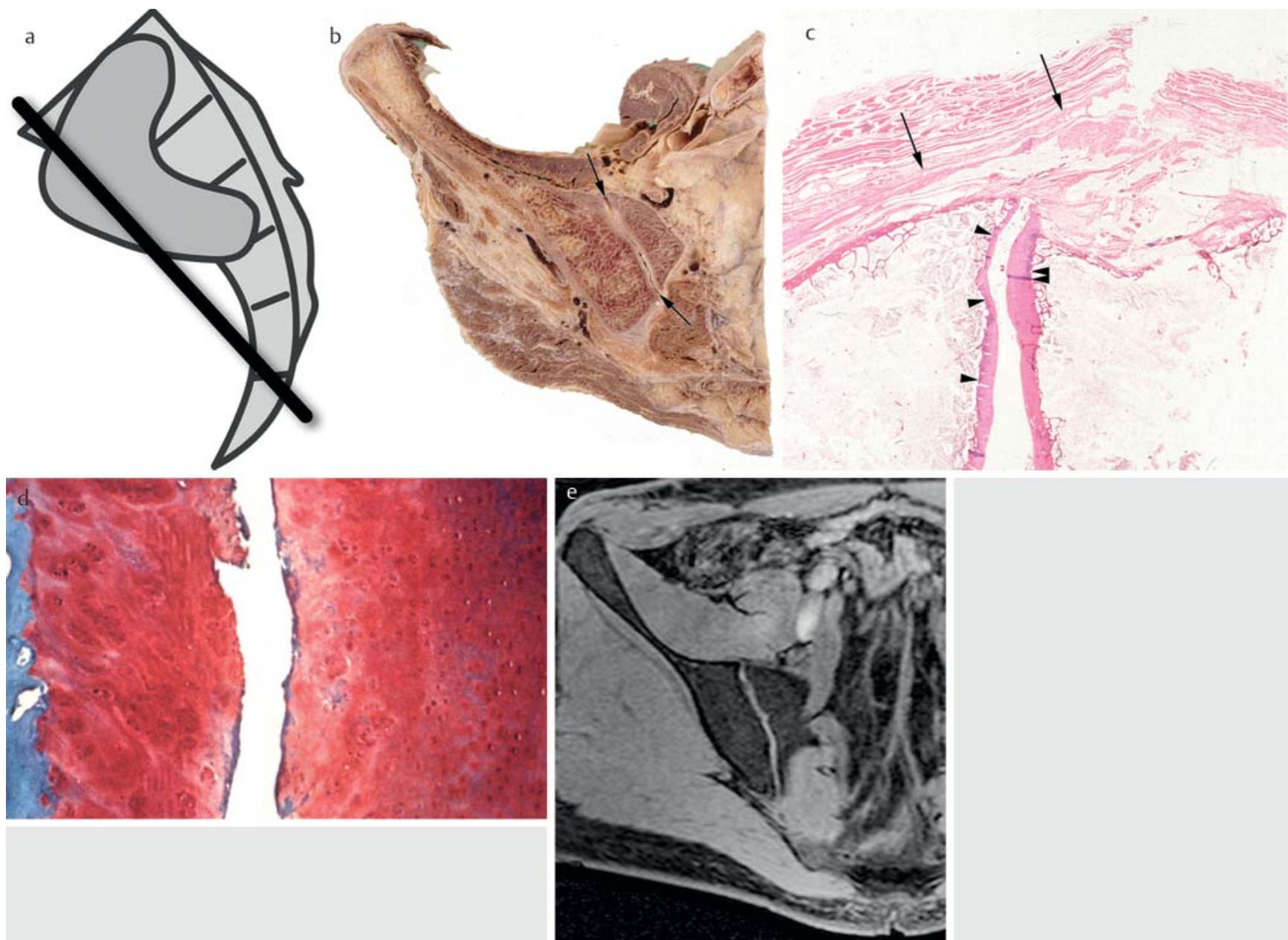

Fig. 1 Normal anterior anatomy of the sacroiliac joints (SIJ). a Schematic representation of the ear-shaped joint surface and of the oblique coronal slice. $\mathbf{b}$ Oblique coronal section of gross anatomic specimen showing the right SIJ (indicated by black arrows) as a continuous structure. c Microanatomic detail of the anterior joint space (H\&E staining, original magnification $\times 10$ ). The articular cartilage on the iliac side (black arrowheads), consisting of a mixture of hyaline and fibrous cartilage, is altogether thinner than the pure hyaline cartilage on the sacral side (black double arrowhead). The anterior sacroiliac ligament (black arrows) gradually blends with the periosteum of the ilium and is therefore considered an enthesis (discontinuity due to cutting artifact). $\mathbf{d}$ Demonstration of iliac fibrocartilage (left) containing collagen fibers and sparse chondrocytes and sacral hyaline cartilage (right) rich in chondrocytes (H\&E staining, original magnification $\times 500$ ). e T1-weighted fat-suppressed 3D gradient echo (GRE) image with high signal intensity of the articular cartilage.
Abb. 1 Normale anteriore Anatomie der Sakroiliakalgelenke (SIG). a Schematische Darstellung der ohrförmigen Gelenkfläche und der schräg koronaren Schnittführung. b Schräg koronare anatomische Präparation des rechten SIG (schwarze Pfeile) mit glatter, durchgängiger Gelenkfläche. c Mikroanatomisches Detail des anterioren Gelenkanteils und der Gelenkkapsel (HE-Färbung, 10fache Vergrößerung). Der iliakale Gelenkknorpel (schwarze Pfeilspitzen), bestehend aus einer Mischung von hyalinem und Faserknorpel, ist dünner als der rein hyaline Gelenkknorpel der sakralen Gelenkfläche (schwarze Doppelpfeilspitze). Das anteriore sakroiliakale Band (schwarze Pfeile) geht kontinuierlich in das Periost des Os ilium über und entspricht einer Enthese (Unterbrechung aufgrund von Schneideartefakten). $\mathbf{d}$ Darstellung des iliakalen Faserknorpels (links) mit Kollagenfasern und spärlichen Chondrozyten und dem sakralen hyalinen Knorpel (rechts) reich an Chondrozyten (HE Färbung, 500fache Vergrößerung). e T1-gewichtete fettsupprimierte wasserverstärkte 3D Gradientenecho (GRE)Sequenz mit hoher Signalintensität des Gelenkknorpels. imaging (MRI) is necessary for evaluating patients with early disease. Demonstration of sacroiliitis is one of the key criteria for axial SpA in the classification of the Assessments in Ankylosing Spondylitis (ASAS) group [3].

SpA patients suffer from pain and stiffening of the axial skeleton and also to some degree the peripheral joints, predominantly the lower extremity. There is a high association with the HLA-B27 antigene and extraskeletal manifestations such as psoriasis, anterior uveitis or inflammatory bowel disease may occur.

The clinical key symptom of SpA is inflammatory back pain characterized by onset before age 40 , insidious onset, relief with movement, no improvement with rest, and pain at night (with improvement after getting up) [4]. Despite this clear definition, the symptoms are often mistaken for chronic low back pain, and an average of 8.5 years elapse after the onset of clinical symptoms before the diagnosis of AS - the prototype of SpA - is made in HLA-B27-positive patients [5]. The delay is even longer, 11.4 years on average, in HLA-B27-negative patients or in women [5]. To improve on this situation, decision-making trees have been proposed to simplify and speed up the diagnosis of SpA [6]. This has been widely acknowledged and as a consequence MRI has been approved to contribute to the classification of SpA in terms of the newly developed ASAS classification criteria [3]. Sensitivities and specificities of over $90 \%[7-10]$ and a high positive likelihood ratio of approx. 9.0 [6] clearly indicate that MRI should be used early so that patients may benefit from early initiation of a 


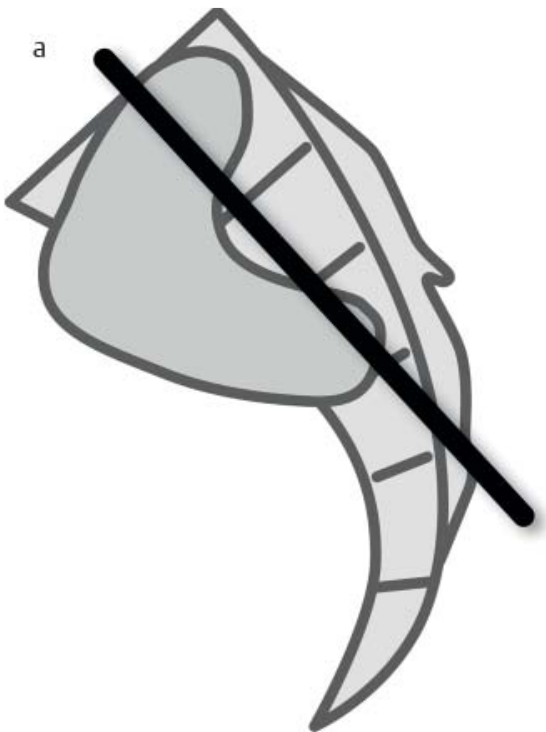

b
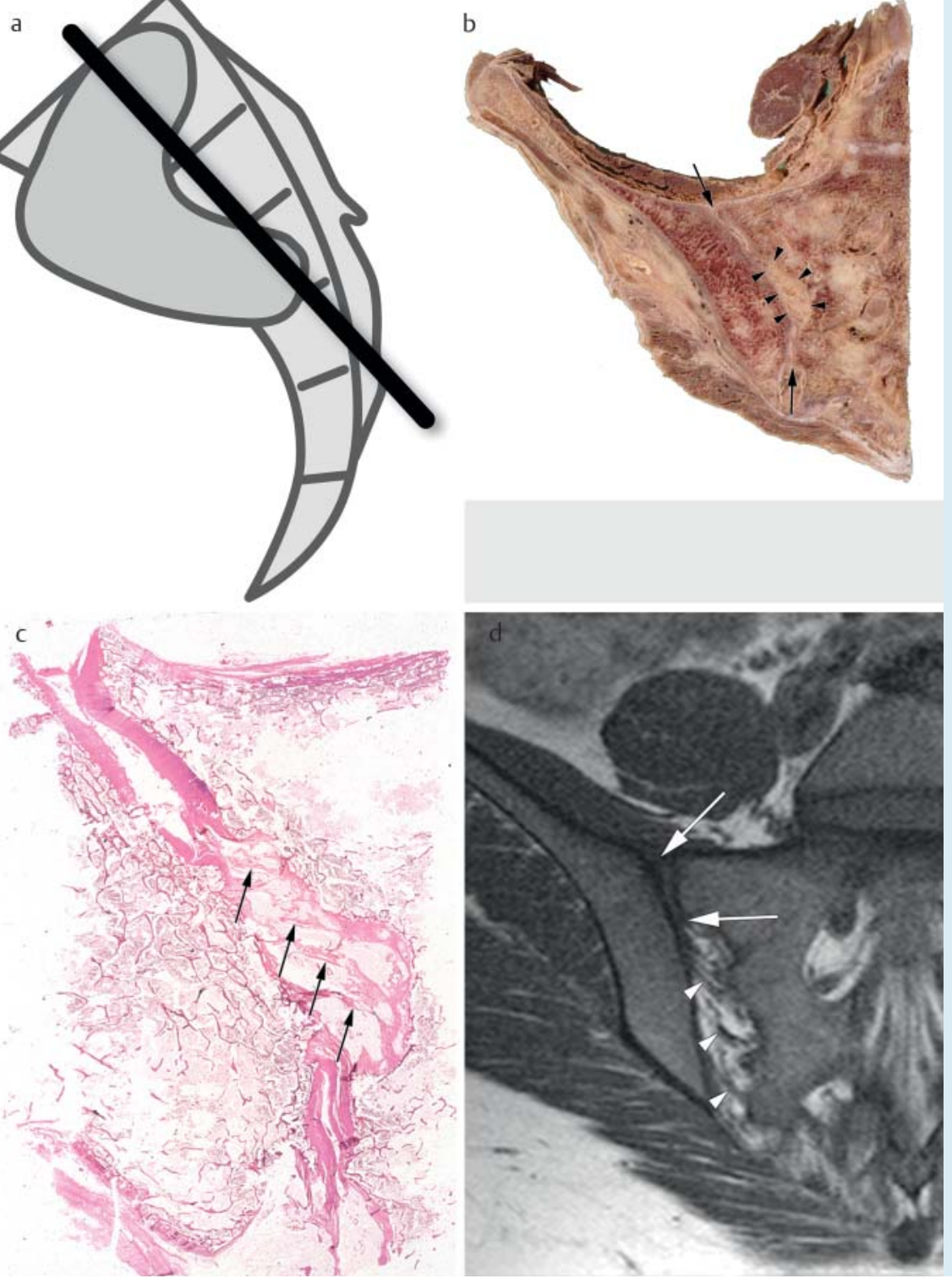

Fig. 2 Normal posterior anatomy. a Schematic representation of the angulated oblique coronal section depicting the cartilaginous portion of the sacroiliac joint superiorly and inferiorly and portions of the fibrous compartment (retroarticular space) in between, which is due to the ear-shaped joint surface. $\mathbf{b}$ Oblique coronal section of gross anatomic specimen. There is smoothly marginated articular cartilage in the cartilaginous compartment (indicated by arrows), while the interosseous ligaments are embedded in fatty tissue in the retroarticular space (black arrowheads). c Microanatomic overview through the plane indicated in a (H\&E staining, original magnification $\times 10$ ). d T1-weighted TSE image of the right SIJ with its anterior cartilaginous part (white arrows) and its posterior retroarticular space containing interosseous ligaments (white arrowheads) and fatty connective tissue.

Abb.2 Normale posteriore Anatomie. a Schematische Darstellung der schräg koronaren Schnittführung mit Darstellung des knorpeligen Gelenkkompartiments superior und inferior sowie Teilen des fibrösen Gelenkkompartiments (Spatium retroarticulare) dazwischen, da die knorpelige Gelenkfläche ohrförmig konfiguriert ist. b Schräg koronare anatomische Präparation. Der Gelenkknorpel ist glatt begrenzt (Pfeile), während die interossären Ligamente in das Fettgewebe des Spatium retroarticulare eingebettet sind (schwarze Pfeilspitzen). c Mikroanatomischer Überblick entsprechend der in a angegebenen Schnittlinie (HE Färbung, 10fache Vergrößerung). d T1-gewichtete TSE Sequenz des rechten SIG mit dem anterioren knorpeligen Gelenkkompartiment (weiße Pfeile) und dem posterior gelegenen Spatium retroarticulare und den dort befindlichen interossären Ligamenten (weiße Pfeilspitzen) und fetthaltigem Bindegewebe.

rigorous therapeutic regimen [11]. The positive likelihood ratio of MRI of the sacroiliac joints (SIJs) is as high as that of the HLA-B27 blood test [6]. However, one has to be aware that a reliable MRI diagnosis of sacroiliitis crucially depends on a thorough clinical history. It has been shown that analysis of MRI alone has a sensitivity of $64 \%$ and a specificity of $80 \%$, which increase to $95 \%$ and $98 \%$, respectively, when images are interpreted in conjunction with clinical data [12].

\section{Anatomy, Histology and Biochemistry as a Basis for Imaging \\ $\nabla$}

Histological examinations of biopsy specimens from the SIJs [13-16] and autopsy preparations [17] have improved our understanding of the pathogenesis of SpA. These specimens, in part also presented in this review article, were acquired in the setting of a research project with approval of the local ethics committee during the course of CT-guided steroid injections in painful patients [16]. In general, joint biopsies are not needed for routine follow-up of SpA patients. As a result of these investigations, the demonstration of tumor necrosis factor alpha (TNFalpha) messenger ribonucleic acid (mRNA) in cellular infiltrates in these biopsy specimens [15] opened up a new era of therapy with TNF-alpha inhibitors [18-21]. MRI of the axial skeleton has an important role in monitoring patients on TNF-alpha therapy [18, $22-24]$.

The complex anatomy of the sacroiliac joints has been described in detail $[25,26]$. MRI of the SIJs is performed in the oblique coronal plane with acquisition of a T1-weighted turbo spin echo (TSE) sequence, a T1-weighted fat-suppressed $3 \mathrm{D}$ gradient echo (GRE) sequence for the depiction of cartilage, and a fat-saturated T1-weighted GRE sequence after contrast administration. The slice thickness should be $1.5-2.0 \mathrm{~mm}$ and dynamic, time-resolved MRI sequences are not generally needed for the diagnosis of sacroiliitis but may be potentially useful in monitoring disease activity $[8,27]$. Alternatively, if contrast medium administration is not possible, a short tau inversion recovery (STIR) sequence may be used. As a recommendation of the ASAS group, a T1weighted TSE sequence and a STIR sequence are sufficient for 

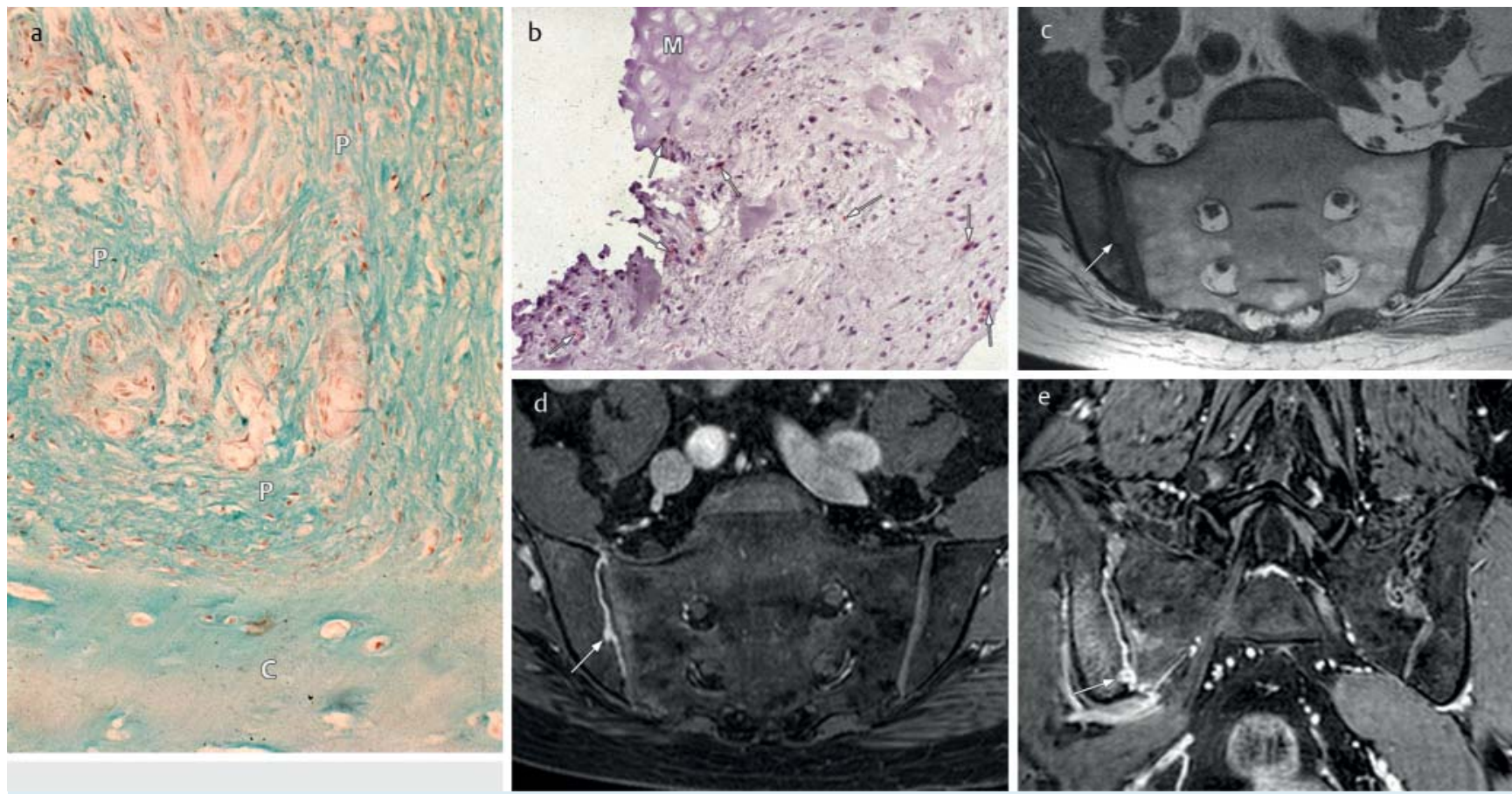

Fig. 3 48-year-old HLA-B27-positive man with early SpA and a threemonth history of inflammatory back pain. a Biopsy specimen (Goldner staining, 250x magnification) showing highly vascularized fibrous proliferation (P) adjacent to cartilage (C). b 500-fold magnification showing the proliferative tissue adjacent to metaplastic cartilage (M). APAAP (alkaline phosphatase anti-alkaline phosphatase) technique with monoclonal antibodies to CD3-positive T-lymphocytes (arrows). c T1-weighted TSE image showing contour irregularities (arrow) and diffuse para-articular signal decrease of the iliac bone. $\mathbf{d}$ T1-weighted oblique coronal fat-saturated image immediately after contrast injection showing linear enhancement of articular fibrocartilage of the right SIJ with clear delineation of single erosion of iliac bone (arrow). Slightly increased signal intensity of the para-articular bone marrow regions suggesting osteitis. Please note normal left SIJ. e T1weighted true coronal fat-saturated image acquired $4 \mathrm{~min}$ after contrast injection demonstrates improved depiction of enthesitis with osteitis predominantly on the iliac side. Arrow indicates same bony erosion as in d (c-e: Original MR images were replaced by equivalent state-of-the-art MR images.)

MRI of the sacroiliac joints [28]. However, these recommendations are intended to be applicable worldwide and therefore may be regarded as the "minimal standard".

The SIJ consists of a cartilaginous part and a fibrous (or ligamentous) compartment with very strong anterior and posterior sacroiliac ligaments [29]. This makes the SIJ an amphiarthrosis with movement restricted to slight rotation and translation [29]. The articular surface being ear-shaped ( $\bullet$ Fig.1a), different articular portions will be depicted, depending on the slice position. Anterior oblique coronal images ( $\bullet$ Fig. 1b, e) only show the cartilaginous joint portion, while more posterior sections ( $\bullet$ Fig. 2a, d) show both cartilaginous and ligamentous portions. Another specific feature of the SIJs is that two different types of cartilage cover the two articular surfaces. While the sacral cartilage is purely hyaline, the iliac side is covered by a mixture of hyaline and fibrous cartilage ( Fig. 1 d) $[29,30]$. Due to its fibrocartilaginous components, the sacroiliac joint is a so-called articular enthesis [31].

The extracellular matrix of fibrocartilage is rich in proteoglycans and glycosaminoglycans, which are strongly hydrophilic mol-
Abb. 3 48-jähriger HLA-B27 positiver Patient mit früher SpA und entzündlichem Rückenschmerz seit drei Monaten. a Gelenkbiopsat (Goldner-Färbung, 250fache Vergrößerung) mit stark vaskularisierter fibröser Proliferation (P) in Nachbarschaft des Knorpels (C). b 500fache Vergrößerung zeigt Proliferationsgewebe metaplastischem Knorpel (M) benachbart. APAAP (alkaline phosphatase anti-alkaline phosphatase) Technik mit monoklonalen Antikörpern gegen CD3-positive T-Lymphozyten (Pfeile). c T1-gewichtete TSE Sequenz zeigt Konturunregelmäßigkeiten (Pfeil) und einen diffusen paraartikulären Signalabfall des Os ilium. d T1-gewichtete schräg koronare fettgesättigte Sequenz unmittelbar nach Kontrastmittelinjektion mit linearem Enhancement des Faserknorpels des rechten SIG und Darstellung einer singulären Erosion im Os ilium (Pfeil). Etwas erhöhte Signalintensität das paraartikulären Knochenmarks hinweisend für Osteitis. Normaler Befund am linken SIG. e T1-gewichtete, streng koronare fettgesättigte Sequenz 4 Min. nach Kontrastmittelinjektion mit verbesserter Darstellung der Enthesitis und Osteitis insbesondere im Os ilium. Der Pfeil markiert die gleiche Erosion wie in $\mathbf{d}$ (c-e: Die originalen MRT-Aufnahmen wurden durch äquivalentes State-of-the-art Bildmaterial ersetzt.)

ecules and attract water, thereby ensuring the stable elasticity of cartilage [32]. Damage to a joint by inflammatory or degenerative processes leads to a loss of these negatively charged macromolecules. As a result, there is greater affinity of gadolinium complexes from paramagnetic contrast agents, which also possess a negative charge, to the extracellular matrix of fibrocartilage [33]. This is the mechanism underlying late enhancement in damaged joints $[34,35]$.

\section{Sacroiliitis and MRI}

Unlike conventional radiography and computed tomography, which only demonstrate structural or chronic changes, MRI depicts both active (acute) and structural signs of sacroiliitis. Active changes are subsumed under the label of enthesitis and include fibrocartilaginous enhancement, predominantly at the iliac joint surface, capsulitis, and juxta-articular osteiitis ( $\bullet$ Fig.4). Florid, or active, stages of sacroiliitis are characterized by proliferative inflammatory tissue destroying cartilage and bone ( $\bullet$ Fig. 4, 5). 

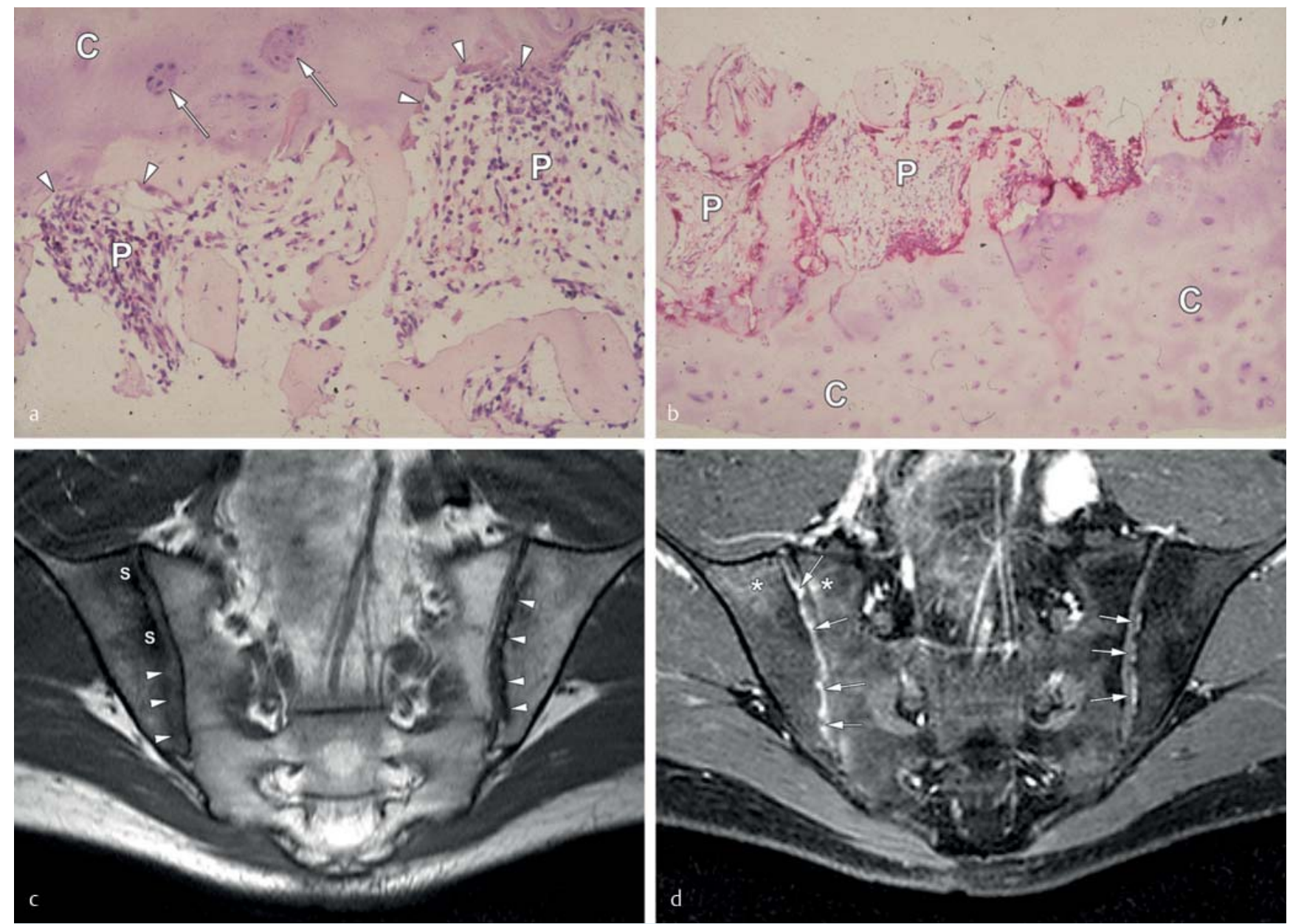

Fig. 4 24-year-old HLA-B27-positive man with early axial SpA and florid sacroiliitis with erosions and a 12-month history of inflammatory back pain. a H\&E staining (original magnification $\times 400$ ) of biopsy specimen of right SIJ. Fibrous proliferation $(\mathrm{P})$ rich in fibroblasts destroying the cartilage $(\mathrm{C})$ with formation of so-called lacunae (arrowheads) and reactive chondroblast activation (arrows) b Immunohistological section of the interface between cartilage $(\mathrm{C})$ and fibrous proliferations $(\mathrm{P})$ with cellular infiltrations (original magnification 250x, APAAP technique, monoclonal antibodies to CD68positive macrophages). c T1-weighted TSE image showing a wavy and blurred cortical layer of the iliac joint surface due to erosions (arrowheads) and patchy iliac subchondral sclerosis on the right SIJ (S) and slight, linear subchondral sclerosis on the left SIJ. Note that the sacral joint surfaces are well preserved due to the thicker hyaline cartilage layer. Fat deposition is evident on both sides of the left SIJ. $\mathbf{d}$ Fat-saturated T1-weighted GRE image in oblique coronal plane after contrast administration showing enhancement of the articular fibrocartilage and of the erosions (arrows) as well as of the para-articular bone marrow (asterisks). Note that the erosions in the left SIJ, which are surrounded by a thin zone of sclerosis, display markedly weaker contrast enhancement. (c, d: Original MR images were replaced by equivalent state-of-the-art MR images.)

Abb. 4 24-jähriger HLA-B27 positiver Patient mit frührer axialer SpA und florider Sakroiliitis mit Erosionen. Seit 12 Monaten bestehender entzündlicher Rückenschmerz. a HE-Färbung (400fache Vergrößerung) eines Gelenkbiopsats des rechten SIG. Fibröse Proliferationen (P) mit zahlreichen Fibroblasten, die den Knorpel (C) zerstören und sogenannte Lakunen (Pfeile) bilden sowie reaktive Aktivierung von Chondroblasten (Pfeile) b Immunohistologische Darstellung des Übergangs zwischen Knorpel (C) und fibrösen Proliferationen (P) mit zellulären Infiltraten (250fache Vergrößerung, APAAP Technik, monoklonale Antikörper gegen CD68-positive Makrophagen). c T1-gewichtete TSE Sequenz mit welliger und unscharfer iliakaler Gelenkkontur aufgrund von Erosionen (arrowheads) und fleckiger iliakaler subchondraler Sklerose (S) des rechten SIG und geringer, linearer subchondraler Sklerose des linken SIG. Die sakralen Gelenkflächen sind gut erhalten aufgrund der dickeren hyalinen Knorpelschicht. Darstellung von Fettdepositionen iliakal und sakral am linken SIG. d Fettgesättigte, schräg koronare T1-gewichtete GRE Sequenz nach Kontrastmittelapplikation mit Enhancement des faserknorpeligen Gelenkknorpels und von Erosionen (Pfeile) sowie paraartikulärer Osteitis (Sterne). Die Erosionen des linken SIG, welche von einer dünnen Sklerosezone umgeben sind, zeigen ein deutlich schwächeres Kontrastmittelenhancement. (c, d: Die originalen MRT-Aufnahmen wurden durch äquivalentes State-of-the-art Bildmaterial ersetzt.)

This tissue consists of fibroblasts and fibrocytes, T-cells, and macrophages [16]. Ingrowth of vessels is one of the reasons why there is a signal increase on contrast-enhanced images ( $\bullet$ Fig. 5). There is controversy about the term "synovitis" because only sparse amounts of synovial, villus-like tissue are histologically demonstrated between the iliac and sacral cartilage near the anterior and posterior joint capsules with obliteration in the further course of the disease [17].

Enthesitis is depicted as contrast medium enhancement of the joint capsule and within the articular fibrocartilage and may extend continuously from the joint to the pericapsular tendon and ligament attachments ( $\bullet$ Fig. 3,4 ). Pericapsular soft tissue (fat and muscle) typically shows no enhancement in spondyloarthritis - which is the case only in septic sacroiliitis (so-called lava cleft phenomenon) [36]. 


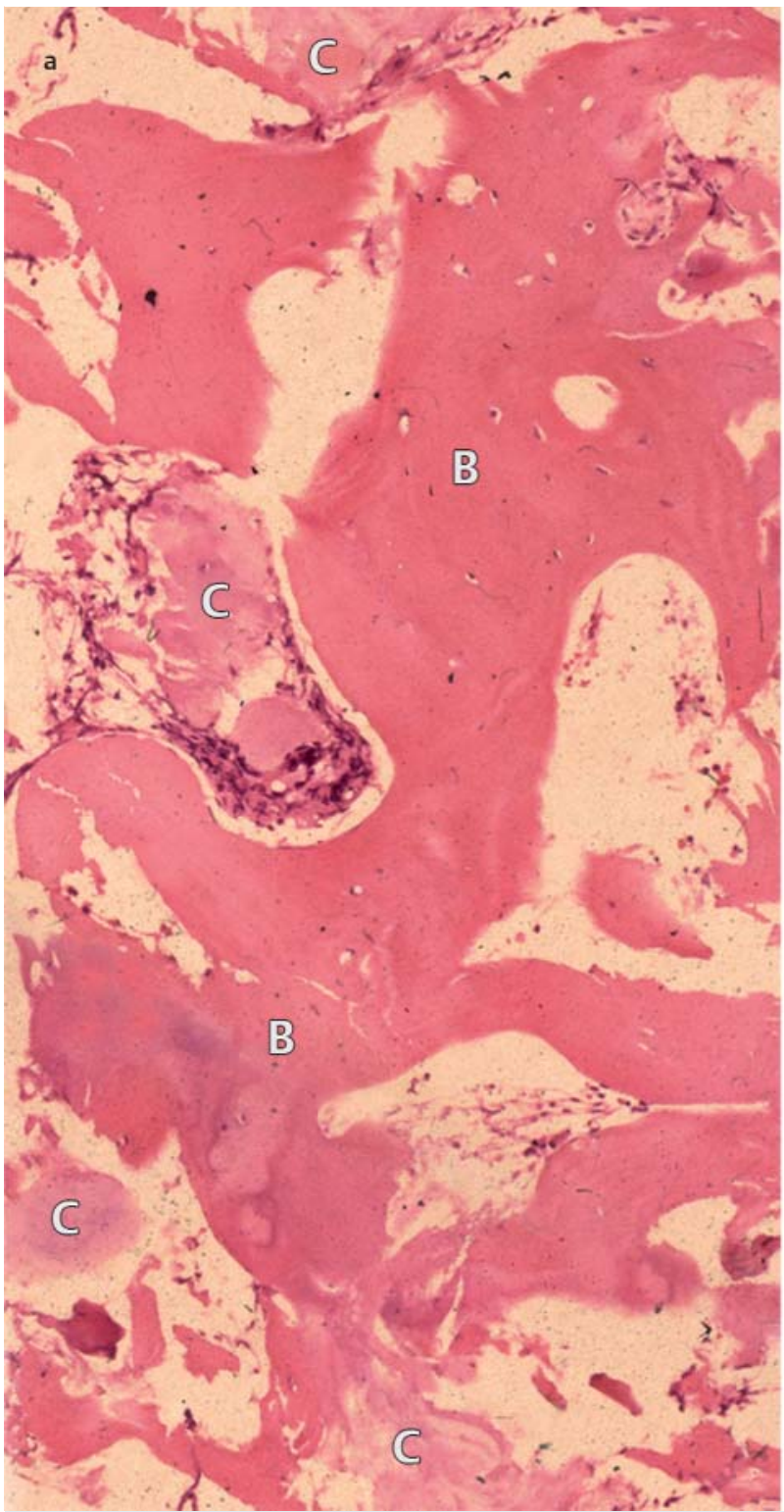

Fig. 5 39-year-old HLA-B27-positive man with AS (10-year history). There is chronic sacroiliitis with low inflammatory activity. a H\&E staining (original magnification $\times 250$ ). The biopsy specimen of the right SIJ shows extensive destruction of cartilage (C) with only residual cartilage fragments and cellular infiltrates and a predominance of trabeculae (B), suggesting formation of new bone. b T1-weighted TSE image showing para-articular sclerosis of both joints, more pronounced on the iliac sides. The joint spaces appear blurred as in early ankylosis. c Fat-saturated, oblique coronal T1-weighted GRE image after contrast administration showing only very sparse enhancement within localized erosions. Corresponding iliac and sacral erosions are visible in both joints. Erosive damage has lead to pseudodilation (arrowhead) of the joints. In addition there are bone buds (arrow) as signs of early ankylosis. (b, c: Original MR images were replaced by equivalent state-of-the-art MR images.)

Early periarticular osteitis denotes inflammation of bone marrow areas adjacent to the sacroiliac joints predominantly on the iliac side ( $\bullet$ Fig. 3). It represents an extension of inflammation of articular fibrocartilage of the SIJs. The size of the bone marrow area affected by osteitis is a measure of the inflammatory activity of sacroiliitis and is graded by using semiquantitative techniques

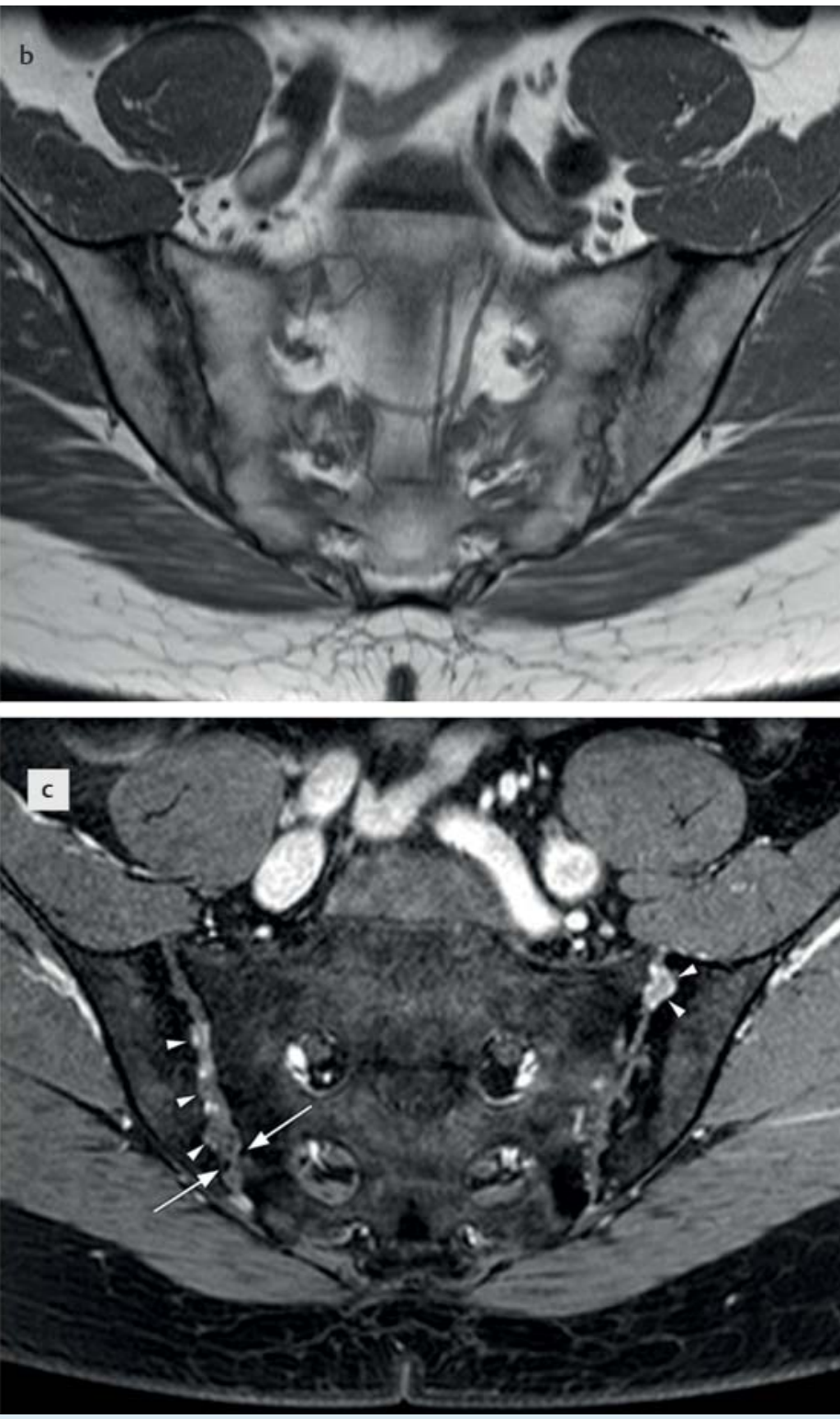

Abb.5 39-jähriger HLA-B27 positiver Patient mit AS (10 Jahre Erkrankungsdauer). Chronische Sakroiliitis mit geringer entzündlicher Aktivität. a HE-Färbung (250fache Vergrößerung). Gelenkbiopsat des rechten SIG zeigt ausgedehnte Zerstörungen des Gelenkknorpels (C) mit residuellen Knorpelfragmenten und zellulären Infiltraten aber prädominanten Trabekeln (B), hinweisend für Knochenneubildung. b T1-gewichtete TSE Sequenz mit paraartikulärer Sklerose beider SIG, betont auf der iliakalen Seite. Die Gelenkspalten erscheinen unscharf wie bei beginnender Ankylose. c Fettgesättigte, schräg koronare T1-gewichtete GRE Sequenz nach Kontrastmittelapplikation und nur sehr spärlichem Enhancement innerhalb von einzelnen Erosionen. Korrespondierende iliakale und sakrale Erosionen beider SIG. Die erosive Zerstörung hat zur Pseudoerweiterung (Pfeilspitzen) der Gelenke geführt. Zusätzlich Darstellung von Knochenknospen (Pfeile) als Zeichen einer beginnenden Ankylose. (b, c: Die originalen MRT-Aufnahmen wurden durch äquivalentes State-of-the-art Bildmaterial ersetzt.)

[25]. Osteitis is also currently the only parameter that defines a positive MRI finding in the classification of the ASAS group, especially when it is present in two or more slices [28]. The signal intensity of osteitis varies with the interval between image acquisition and contrast medium injection ( $\bullet$ Fig. $\mathbf{3}$ ). 


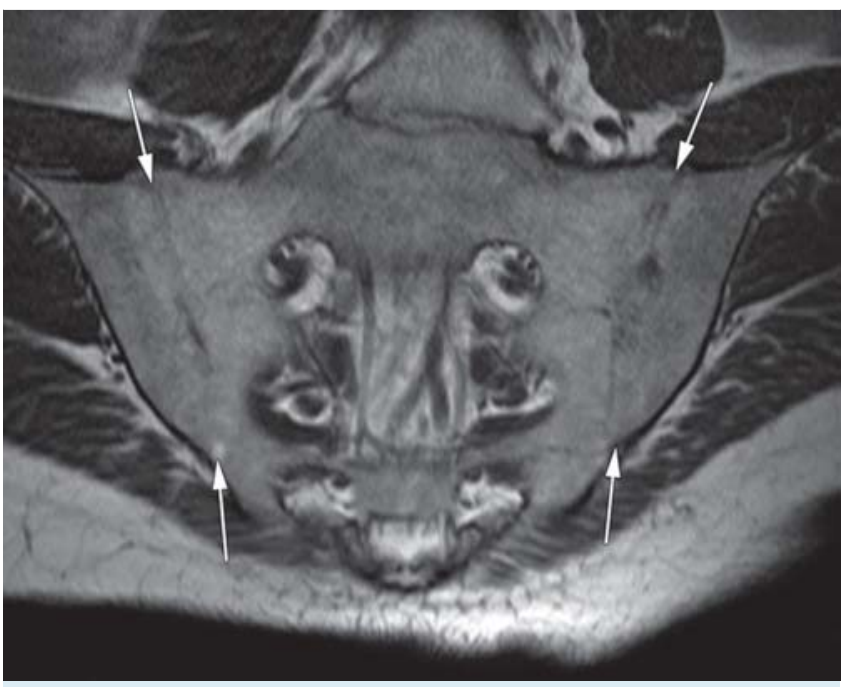

Fig. 6 33-year-old HLA-B27-positive patient with a long history of AS. T1weighted TSE image showing complete ankylosis of both sacroiliac joints. "Phantom joints" suggest the former joints (arrows).

Abb. 6 33-jähriger HLA-B27 positiver Patient mit langjährig bekannter AS. T1-gewichtete TSE Sequenz mit kompletter Ankylose beider SIG. "Phantomgelenke" deuten die ehemaligen SIG an (Pfeile).

At later stages areas of osteitis are transformed into periarticular deposits of fatty tissue [25, 37]. Chronic sacroiliitis is further characterized by erosions, subchondral sclerosis, transarticular bone bridges, and bone buds ( $\boldsymbol{\bullet}$ Fig. $\mathbf{5}, \mathbf{6}$ ). These processes may ultimately lead to complete ankylosis of the sacroiliac joints, which is seen on MRI as a so-called phantom joint.

Erosions are depicted on MR images as discontinuities of the cortical bone. Erosions are contiguous with the joint space. Erosions in sacroiliac arthritis initially tend to occur on the iliac side of the joint [38], due to its fibrocartilaginous components, and may later progress to corresponding erosions also on the sacral side ( 0 Fig. 5). Strong contrast enhancement indicates active erosion, while so-called smooth erosions display much weaker enhancement and are characterized by the presence of marginal sclerosis ( 0 Fig. 4). Several confluent erosions have the appearance of a string of beads and lead to so-called pseudodilation of the sacroiliac joint as they progress further ( $\boldsymbol{0}$ Fig. 5).

Subchondral sclerosis is seen as areas of low or no signal on all sequences. They often predominate on the iliac side ( $\bullet$ Fig. 4 ) and only later affect the periarticular area on the sacral side as well (० Fig. 5). Sclerosis shows no enhancement after contrast medium administration.

Bone buds ( $\bullet$ Fig. 5 ) and transarticular bone bridges are the first sign of ankylosing processes of the SIJ. They are more clearly identified by computed tomography since bony structures are depicted only indirectly on MR images. The presence of bone bridges leads to increasing blurring of the joint cleft until complete ankylosis occurs. Transarticular bone bridges are characterized by low signal intensity on all sequences. When there is complete ankylosis, the SIJ is seen as a low-intensity line surrounded by deposits of fatty tissue, which is hyperintense on T1-weighted images. This condition is referred to as a phantom joint ( $\bullet$ Fig. 6).

\section{Summary}

$\nabla$

In summary, MRI of the sacroiliac joints sensitively detects both active and structural changes, making it an ideal imaging modality for early diagnosis and follow-up of sacroiliitis in axial spondyloarthritis. Some of the changes are subtle and can only be detected after administration of a paramagnetic contrast agent, especially in early disease.

\section{Acknowledgement}

$\nabla$

This article is dedicated to Professor Bernd Hamm on the occasion of his 60th birthday.

\section{References}

1 van der Linden S, Valkenburg HA, Cats A. Evaluation of diagnostic criteria for ankylosing spondylitis. A proposal for modification of the New York criteria. Arthritis Rheum 1984; 27: 361 - 368

2 Dougados $M$, van der Linden S, Juhlin R et al. The European Spondylarthropathy Study Group preliminary criteria for the classification of spondylarthropathy. Arthritis Rheum 1991; 34: 1218-1227

3 Rudwaleit M, van der Heijde D, Landewe R et al. The development of Assessment of SpondyloArthritis international Society classification criteria for axial spondyloarthritis (part II): validation and final selection. Ann Rheum Dis 2009; 68: 777-783

4 Sieper J, van der Heijde D, Landewe R et al. New criteria for inflammatory back pain in patients with chronic back pain: a real patient exercise by experts from the Assessment of SpondyloArthritis international Society (ASAS). Ann Rheum Dis 2009; 68: 784 - 788

5 Feldtkeller E, Khan MA, van der Heijde D et al. Age at disease onset and diagnosis delay in HLA-B27 negative vs. positive patients with ankylosing spondylitis. Rheumatol Int 2003; 23: 61 -66

6 Rudwaleit $M$, van der Heijde D, Khan MA et al. How to diagnose axial spondyloarthritis early. Ann Rheum Dis 2004; 63: 535-543

7 Braun J, Bollow M, Eggens $U$ et al. Use of dynamic magnetic resonance imaging with fast imaging in the detection of early and advanced sacroiliitis in spondylarthropathy patients. Arthritis Rheum 1994; 37: $1039-1045$

8 Bollow M, Braun J, Hamm B et al. Early sacroiliitis in patients with spondyloarthropathy: evaluation with dynamic gadolinium-enhanced MR imaging. Radiology 1995; 194: 529-536

9 Blum U, Buitrago-Tellez C, Mundinger A et al. Magnetic resonance imaging (MRI) for detection of active sacroiliitis: A prospective study comparing conventional radiography, scintigraphy, and contrast enhanced MRI. J Rheumatol 1996; 23: 2107-2115

10 Puhakka KB, Jurik AG, Egund $N$ et al. Imaging of sacroiliitis in early seronegative spondylarthropathy. Assessment of abnormalities by MR in comparison with radiography and CT. Acta Radiol 2003; 44: 218-229

11 Song IH, Hermann K, Haibel H et al. Effects of etanercept versus sulfasalazine in early axial spondyloarthritis on active inflammatory lesions as detected by whole-body MRI (ESTHER): a 48-week randomised controlled trial. Ann Rheum Dis 2011; 70: 590-596

12 Remplik $P$, Schukai 0 , Roemer FW et al. Influence of clinical information on the diagnostic validity of MRI in the detection of abacterial sacroiliitis. Fortschr Röntgenstr 2005; 177: $842-848$

13 Dihlmann $W$, Lindenfelser $R$, Selberg $W$. Histomorphology of the sacroiliac joint in ankylosing spondylitis and relevance to treatment (author's transl). Dtsch Med Wochenschr 1977; 102: 129-132

14 Shichikawa K, Tsujimoto M, Nishioka J et al. Histopathology of early sacroiliitis and enthesitis in ankylosing spondylitis: advances in inflammation research. In: Ziff M, Cohen SB. eds The spondyloarthropathies New York: NY: Raven; 1985: 15-24

15 Braun J, Bollow M, Neure L et al. Use of immunohistologic and in situ hybridization techniques in the examination of sacroiliac joint biopsy specimens from patients with ankylosing spondylitis. Arthritis Rheum 1995; 38: 499-505

16 Bollow M, Fischer T, Reisshauer $H$ et al. Quantitative analyses of sacroiliac biopsies in spondyloarthropathies: T cells and macrophages predominate in early and active sacroiliitis- cellularity correlates with the 
degree of enhancement detected by magnetic resonance imaging. Ann Rheum Dis 2000; 59: 135 - 140

17 Francois RJ, Gardner DL, Degrave EJ et al. Histopathologic evidence that sacroiliitis in ankylosing spondylitis is not merely enthesitis. Arthritis Rheum 2000; 43: 2011 - 2024

18 Brandt J, Haibel H, Cornely D et al. Successful treatment of active ankylosing spondylitis with the anti-tumor necrosis factor alpha monoclonal antibody infliximab. Arthritis Rheum 2000; 43: 1346-1352

19 Braun J, Brandt J, Listing J et al. Treatment of active ankylosing spondylitis with infliximab: a randomised controlled multicentre trial. Lancet 2002; 359: 1187 - 1193

20 Davis JCJr, Van Der Heijde D, Braun J et al. Recombinant human tumor necrosis factor receptor (etanercept) for treating ankylosing spondylitis: a randomized, controlled trial. Arthritis Rheum 2003; 48: 3230 3236

21 van der Heijde D, Kivitz A, Schiff MH et al. Efficacy and safety of adalimumab in patients with ankylosing spondylitis: results of a multicenter, randomized, double-blind, placebo-controlled trial. Arthritis Rheum 2006; 54: 2136-2146

22 Marzo-Ortega H, McGonagle D, O'Connor P et al. Efficacy of etanercept in the treatment of the entheseal pathology in resistant spondylarthropathy: a clinical and magnetic resonance imaging study. Arthritis Rheum 2001; 44: $2112-2117$

23 Braun J, Baraliakos X, Golder W et al. Magnetic resonance imaging examinations of the spine in patients with ankylosing spondylitis, before and after successful therapy with infliximab: evaluation of a new scoring system. Arthritis Rheum 2003; 48: 1126 - 1136

24 Haibel $H$, Rudwaleit $M$, Brandt $H C$ et al. Adalimumab reduces spinal symptoms in active ankylosing spondylitis: clinical and magnetic resonance imaging results of a fifty-two-week open-label trial. Arthritis Rheum 2006; 54: 678-681

25 Hermann KG, Braun J, Fischer T et al. Magnetic resonance imaging of sacroiliitis: anatomy, histological pathology, MR-morphology, and grading. Radiologe 2004; 44: $217-228$

26 Bollow M, Braun J, Hermann KG. Sakroiliakalgelenk (mit Exkurs: Spinale Entzündungsmuster rheumatischer Erkrankungen). In: Vahlensieck M, Reiser M. eds Magnetresonanztomographie des muskuloskelettalen Systems Stuttgart: Thieme; 2006

27 Gaspersic N, Sersa I, Jevtic V et al. Monitoring ankylosing spondylitis therapy by dynamic contrast-enhanced and diffusion-weighted magnetic resonance imaging. Skeletal Radiol 2008; 37: 123-131
28 Rudwaleit M, Jurik AG, Hermann KG et al. Defining active sacroiliitis on Magnetic Resonance Imaging (MRI) for classification of axial spondyloarthritis - a consensual approach by the ASAS/OMERACT MRI Group. Ann Rheum Dis 2009; 68: 1520 - 1527

29 Kampen WU, Tillmann B. Age-related changes in the articular cartilage of human sacroiliac joint. Anatomy and embryology 1998; 198: $505-$ 513

30 McLauchlan GJ, Gardner DL. Sacral and iliac articular cartilage thickness and cellularity: relationship to subchondral bone end-plate thickness and cancellous bone density. Rheumatology (Oxford) 2002; 41: $375-380$

31 Benjamin M, McGonagle D. The anatomical basis for disease localisation in seronegative spondyloarthropathy at entheses and related sites. J Anat 2001; 199: 503-526

32 Aktas T. Die molekulare Zusammensetzung der extrazellulären Matrix des Lig. scapholunatum. München: Munich Ludwig-Maximilians-Universität; 2006

33 Bashir A, Gray ML, Hartke J et al. Nondestructive imaging of human cartilage glycosaminoglycan concentration by MRI. Magnetic resonance in medicine: official journal of the Society of Magnetic Resonance in Medicine/Society of Magnetic Resonance in Medicine 1999; 41: 857 865

34 Williams A, Gillis A, McKenzie C et al. Glycosaminoglycan distribution in cartilage as determined by delayed gadolinium-enhanced MRI of cartilage (dGEMRIC): potential clinical applications. Am J Roentgenol Am J Roentgenol 2004; 182: 167-172

35 Taupitz M, Stolzenburg N, Ebert $M$ et al. Gadolinium-containing magnetic resonance contrast media: investigation on the possible transchelation of $\mathrm{Gd}(3)(+)$ to the glycosaminoglycan heparin. Contrast media \& molecular imaging 2013; 8: 108 - 116

36 Stürzenbecher A, Braun J, Paris $S$ et al. MR imaging of septic sacroiliitis. Skeletal Radiol 2000; 29: 439-446

37 Bollow M, Braun J, Taupitz M et al. CT-guided intraarticular corticosteroid injection into the sacroiliac joints in patients with spondyloarthropathy: indication and follow-up with contrast-enhanced MRI. J Comput Assist Tomogr 1996; 20: 512 - 521

38 Bollow M, Hermann KGA, Biedermann $T$ et al. Very early spondyloarthritis: where the inflammation in the sacroiliac joints starts. Ann Rheum Dis 2005; 64: 1644-1646 